Article

\title{
Microstructure of rapidly quenched Ni-Al based catalysts by advanced electron microscopy
}

\author{
Bingsen Zhang a, $\dagger$, Aiguo Zheng b, + , Xiaoli Pan a , Yiming Niu a, Xiaoxin Zhang b, Dangsheng Su a,*, \\ Baoning Zong b,\# \\ a Shenyang National Laboratory for Materials Science, Institute of Metal Research, Chinese Academy of Sciences, Shenyang 110016, Liaoning, China \\ ${ }^{\mathrm{b}}$ State Key Laboratory of Catalytic Materials and Reaction Engineering, Research Institute of Petroleum Processing, Sinopec, Beijing 100083, China
}

\section{A R T I C L E I N F O}

\section{Article history:}

Received 3 April 2015

Accepted 3 June 2015

Published 20 October 2015

\section{Keywords:}

Nickel-aluminum based catalyst

Electron microscopy

Spectroscopy

Vacuum transfer holder

Microstructure

\begin{abstract}
A B S T R A C T
The microstructure of air-sensitive Raney-type catalysts directly determines their activity and selectivity for a catalytic reaction. The fine structure of a rapidly quenched $\mathrm{Ni}-\mathrm{Al}$ alloy doped with $\mathrm{Fe}$ and $\mathrm{Cr}$ (RQ Ni-Al-FC) was investigated by electron microscopy imaging and spectroscopic techniques, and its structure was successfully characterized by using a vacuum transfer holder in the transmission electron microscope. The microstructural comparison of pristine and passivated/combusted samples was discussed in detail. This work provides the structure of RQ Ni-Al based catalysts as a contribution to exploring their synthesis-structure-performance relationship.
\end{abstract}

(C) 2015, Dalian Institute of Chemical Physics, Chinese Academy of Sciences. Published by Elsevier B.V. All rights reserved.

\section{Introduction}

Raney-type catalysts with superior electronic, magnetic, mechanical, and chemical properties have been extensively used in the petrochemical industry [1-3]. They are prepared by the rapid quenching technique to obtain a metastable and uniform alloy with an amorphous or nanocrysalline microstructure [4-10]. For instance, skeletal Ni alloy prepared by the alkali dissolution of the rapidly quenched $\mathrm{Ni}-\mathrm{Al}$ alloy (RQ $\mathrm{Ni}-\mathrm{Al}$ ) exhibits remarkable performance in the hydrogenation of unsaturated organic compounds [4-6]. The hydrogenation activity, acid resistance, and magnetic property can be varied by the addition of appropriate heteroatoms, thus giving rise to a family of RQ Ni-Al based catalysts tailored precisely for a specific purpose $[1-3,10]$. For example, the introduction of Fe can increase the magnetically susceptibility, which copes with the needs of the magnetic separation technique and magnetically stabilized bed $[1,10]$. The adding of the corrosionresistant $\mathrm{Cr}$ enables the catalyst to be used in an acidic reaction system $[1,11]$. The thermal stability and specific surface area play key roles in enhancing the performance of Raney-type catalysts $[2,6,7,12,13]$, which depend on the phase composition, crystallite size, pore size distribution, and the introduction of the heteroatom. Therefore, the fine structures of the RQ Ni-Al based catalyst is crucial for exploring the correlation between the microstructural features and active phase. Devred et al. [14] obseved the structure of Raney-type catalysts by vacuum transfer holder transmission electron microscopy (TEM) in the

\footnotetext{
* Corresponding author. Tel: +86-24-23971577; Fax: +86-24-83970019; E-mail: dssu@imr.ac.cn

\# Corresponding author. E-mail: zongbn.ripp@sinopec.com

+ These authors contributed equally to this work.

This work was supported by the State Key Laboratory of Catalytic Materials and Reaction Engineering (RIPP, SINOPEC), the Key Innovative Project of Institute of Metal Research, Chinese Academy of Sciences (CAS), and the Youth Innovation Promotion Association CAS. DOI: 10.1016/S1872-2067(15)60925-1 | http://www.sciencedirect.com/science/journal/18722067 | Chin. J. Catal., Vol. 36, No. 10, October 2015
} 
TEM and high resolution TEM (HRTEM) modes, and related them to the performance. However, there actually are only few reports on the fine structure issues. It is difficult to prepare the TEM specimen due to the spontaneous combustion that occurs when the sample is exposed in air. In addition, the magnetism of Raney-type catalysts also affect the characterization in TEM at the atomic level. Based on present knowledge of the Raney-type catalyst studied by X-ray diffraction (XRD) and X-ray photoelectron spectroscopy (XPS) $[15,16]$, it is of great interest to explore the detailed structure by advanced electron microscopy and associate techniques (e.g., energy dispersive X-ray spectroscopy (EDS) and electron energy loss spectroscopy (EELS)) at the atomic scale. In the present work, we investigated the morphology, phase composition, distribution of the constituent elements, and electron structure of an RQ Ni-Al alloy doped with Fe and Cr (RQ Ni-Al-FC) by advanced electron microscopy and spectroscopy. The microstructural comparison of the sample protected by a vacuum transfer TEM holder and that after passivation and after spontaneous combustion was studied and discussed. Our work provides valuble information for unraveling the catalytic mechanism and understanding the reaction pathway of RQ $\mathrm{Ni}-\mathrm{Al}$ alloy based catalysts in chemical reactions.

\section{Experimental}

\subsection{Synthesis of a series of RQ Ni-Al-FC catalysts}

The RQ Ni-Al-FC alloy ribbon was prepared by a single-roller melt-spinning method $[6,7,12]$. Then the ribbon was ground to 200 mesh and added slowly to a $\mathrm{NaOH}$ solution (5 mol/L) with vigorous stirring. The RQ Ni-Al-FC catalyst obtained was washed with distilled water and then with ethanol.

The combusted sample was prepared by putting the pristine RQ Ni-Al-FC sample in air. It was spontaneously combusted and then was collected for TEM characterization.

The pristine RQ Ni-Al-FC catalyst that was stored in ethanol was put into a furnace. The air in the sealed furnace was expelled by flowing Ar at room temperature (RT) for $0.5 \mathrm{~h}$. Subsequently, the sample was heated to $110{ }^{\circ} \mathrm{C}$ and kept for $6 \mathrm{~h}$ to dry the sample in Ar. The sample was then cooled to RT. The flow rate of Ar was $200 \mathrm{~mL} / \mathrm{min}$. Finally, the passivation gas $\left(0.5 \% \mathrm{O}_{2} / \mathrm{He}, 100 \mathrm{~mL} / \mathrm{min}\right)$ was passed through the furnace at RT for $11 \mathrm{~h}$.

\subsection{TEM investigation}

The RQ Ni-Al-FC sample was transferred into the microscope without contact with air by a vacuum transfer holder. The combusted and passivated RQ Ni-Al-FC samples were ultrasonically dispersed in ethanol, and then a drop of the solution was deposited onto a holey $\mathrm{C} / \mathrm{Cu}$ TEM grid to be used for TEM characterization. A FEI Tecnai G2 F20 microscope equipped with Gatan Image Filter (GIF) operated at $200 \mathrm{kV}$ was employed to conduct the structural investigation of the series of RQ Ni-Al-FC samples in both TEM and STEM modes.

\subsection{Surface and structure analysis}

A X-ray diffractometer (XRD; $\left.\mathrm{Cu}-K_{\alpha}\right)$ was used to verify the crystalline structure. The surface morphology of the RQ Ni-Al-FC sample was characterized by a FEI NOVA NANOSEM 450 operated at $15 \mathrm{kV}$.

\section{Results and discussion}

The RQ Ni-Al-FC catalyst was prepared by the rapid quenching method, followed by alkaline extraction. Figure 1(a) shows the XRD pattern of the RQ Ni-Al-FC catalyst. Besides the diffraction peaks of the Ni nanocrystal (111), (200), and (220) planes as the main crystalline phase in the RQ Ni-Al-FC sample, the characteristic diffraction peaks of the $\mathrm{Ni}_{2} \mathrm{Al}_{3}$ (011), (110), (012), (202), and (122) planes can also be indexed. There was no other phase detected by XRD other than $\mathrm{Ni}$ and $\mathrm{Ni}_{2} \mathrm{Al}_{3}$. Figures 1(b) and (c) show the TEM image of RQ Ni-Al-FC sample together with the corresponding selective area electron diffraction (SAED) pattern. From the corresponding $d$ values, we can identify these as showing the $\mathrm{Ni}$ and $\mathrm{Ni}_{2} \mathrm{Al}_{3}$ phases, which was consistent with the XRD results.

Figure 2 displays the scanning TEM-EDS (STEM-EDS) elemental maps and the EDS spectrum of a typical region in the RQ Ni-Al-FC sample. These showed that all constituent elements, $\mathrm{Ni}, \mathrm{Al}, \mathrm{Fe}, \mathrm{Cr}$, and $\mathrm{O}$, were homogeneously distributed in this area. Some 0 existed in the RQ Ni-Al-FC catalyst, but the oxide was not detected by XRD. Furthermore, the small amount of Fe and $\mathrm{Cr}$ was quantified by EDS (Fig. 2(c)), giving the atomic ratio of $\mathrm{Al}: \mathrm{Cr}: \mathrm{Fe}: \mathrm{Ni}=11.03: 1.87: 1.11: 85.99$, which was consistent with the preparation target. To show the fine structures of the RQ Ni-Al-FC catalyst, TEM observations were conducted (Fig.
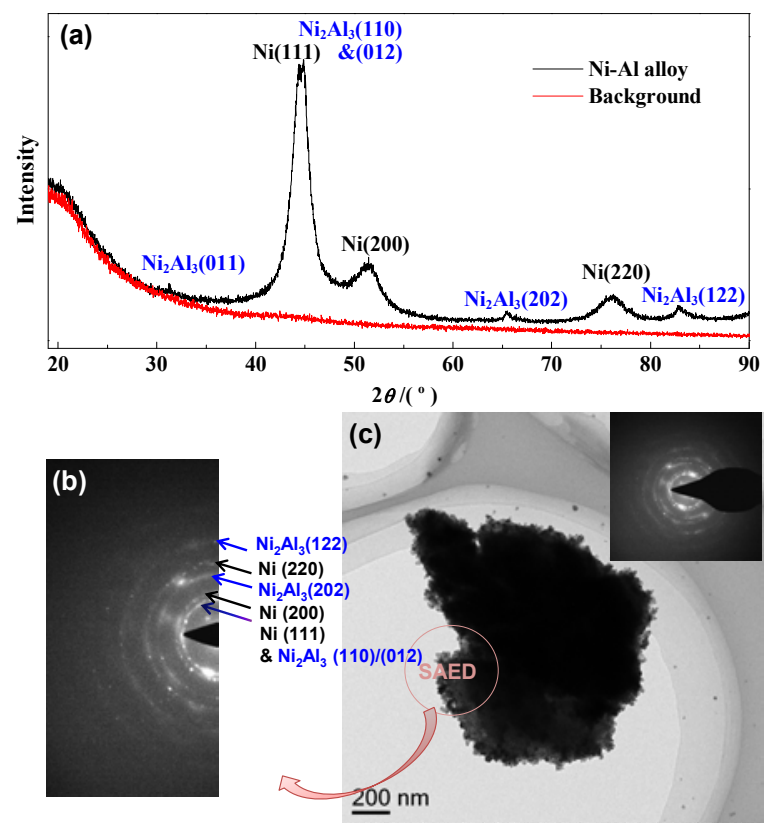

Fig. 1. XRD patterns (a), analysis of SAED (b), and low magnification TEM image (c) of RQ Ni-Al-FC catalyst. The sample was sealed in the XRD holder, so there was some background in the pattern. The XRD analysis referred to JCPDS cards (65-0380 and 65-3454). 

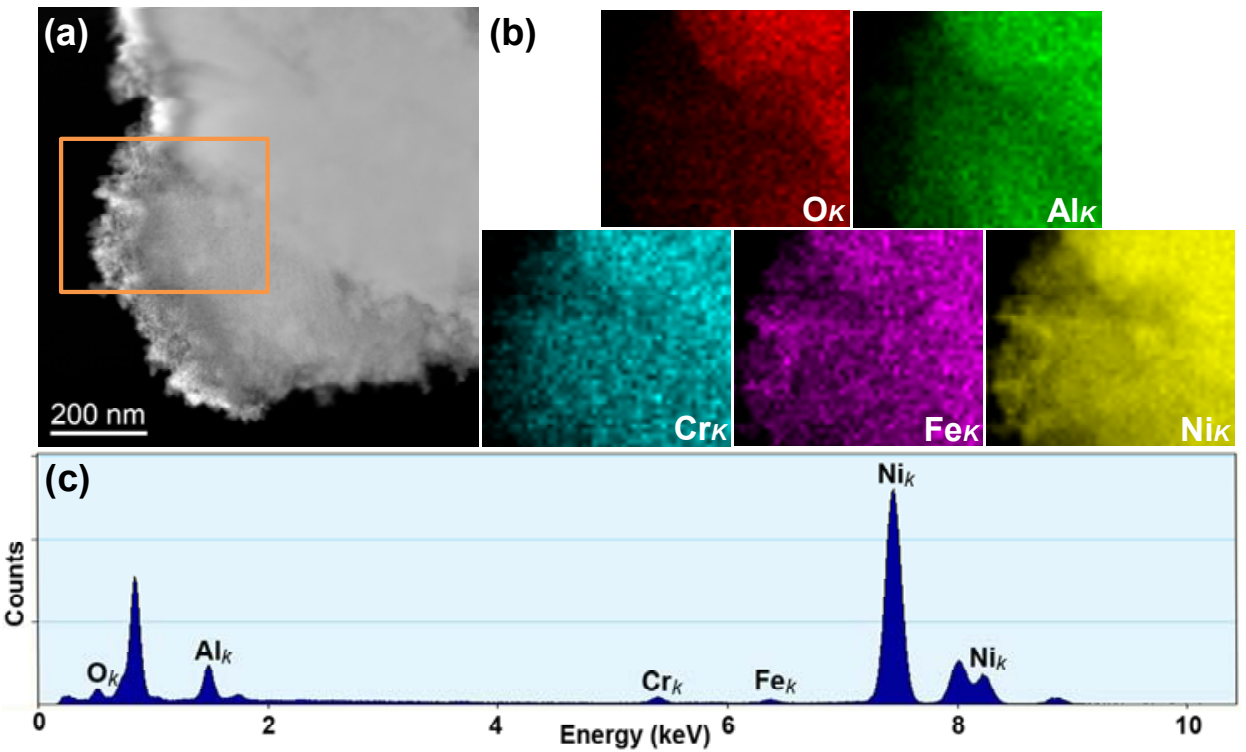

Fig. 2. A typical HAADF-STEM image (a), EDS elemental maps (b), and EDS spectrum (c) of the RQ Ni-Al-FC catalyst.

3). The nanocrystal particle size distribution (PSD) was uniform, and the average size was $6 \mathrm{~nm}$ (Fig. 3(a)). The lattice spacings measured in Figs. 3(b) and (c) showed an interplanar spacing of $2.04 \AA$ determined as the (111) basal planes of crystalline $\mathrm{Ni}$, and an interplanar spacing of $2.85 \AA$ determined as the (011) basal planes of crystalline $\mathrm{Ni}_{2} \mathrm{Al}_{3}$, which was consistent with XRD results. No crystalline phase of Fe and Cr was found in the HRTEM images. These atoms would be doped in the $\mathrm{Ni}$ crystal lattice to substitute $\mathrm{Ni}$ atoms or existed as nanoclusters that were too small. In addition, a NiO nanocrystal was identified in Fig. 3(d), which was otherwise seldom seen in the sample. This result explained why there was a little amount of $\mathrm{O}$ detected by EDS, as shown in Fig. 2.

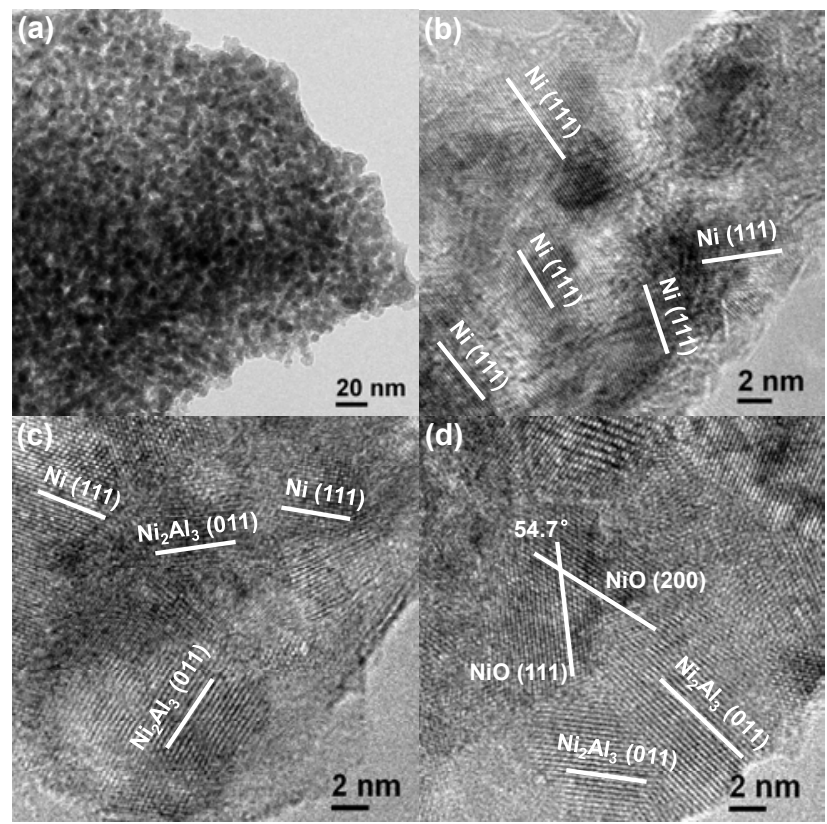

Fig. 3. Typical low magnification TEM (a) and HRTEM (b-d) images of RQ Ni-Al-FC.
The existence and structural information of $\mathrm{O}, \mathrm{Al}, \mathrm{Fe}, \mathrm{Ni}$, and $\mathrm{Cr}$ in RQ Ni-Al-FC catalyst were also obtained by EELS. Figure 4 shows the $\mathrm{O} K, \mathrm{Al} L, \mathrm{Fe} L, \mathrm{Ni} L$, and $\mathrm{Cr} L$ edges. The energy loss from 180 to $500 \mathrm{eV}$ showed no peak in this region, which indicated that there was no $\mathrm{C}$ in this catalyst. By reference to the reference metal or metal oxide for the peak position, peak shape and white line ratio in the EELS spectra [17-23], most of the $\mathrm{Ni}, \mathrm{Fe}$, and $\mathrm{Cr}$ existed as metal $\mathrm{Ni}$, metal $\mathrm{Fe}$, and oxide $\mathrm{Cr}$, respectively. Furthermore, the quantitative analysis of the composition showed the same results as the EDS spectrum.

The microstructural information discussed above was investigated with the use of the vacuum transfer TEM holder. We also studied the combusted and passivated samples for comparing with the pristine RQ Ni-Al-FC sample. Much crystalline $\mathrm{NiO}$ was identified by XRD and SAED to exist in the combusted RQ Ni-Al-FC sample. The EELS spectrum also revealed that the $O$ content increased in the sample that had undergone spontaneous combustion. Therefore, less useful information can be obtained because the original structure features have been

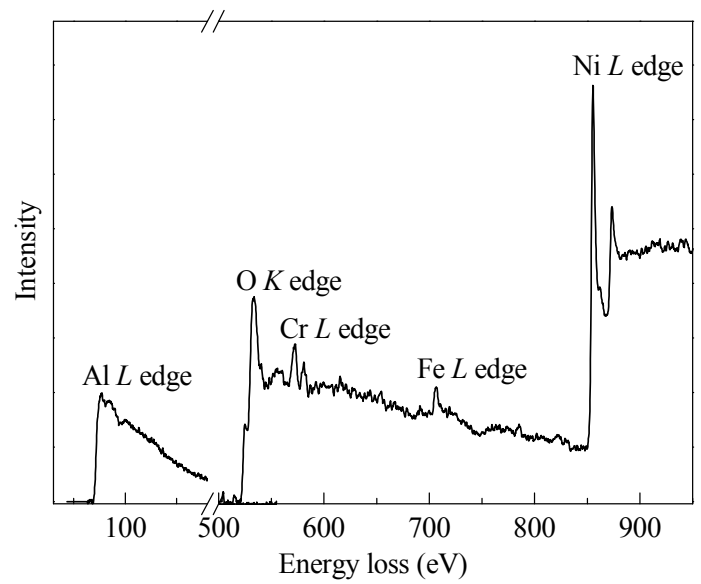

Fig. 4. EELS spectrum of RQ Ni-Al-FC catalyst, showing $\mathrm{Al} L, O K, \mathrm{Cr} L, \mathrm{Fe}$ $L$, and $\mathrm{Ni} L$ edges. 


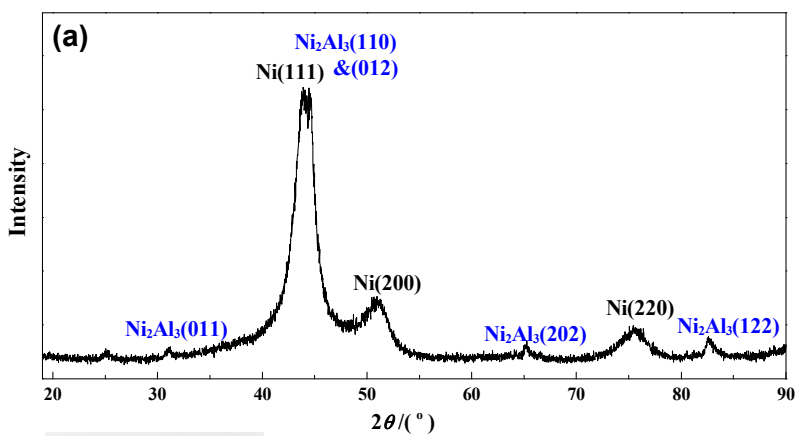

(b)

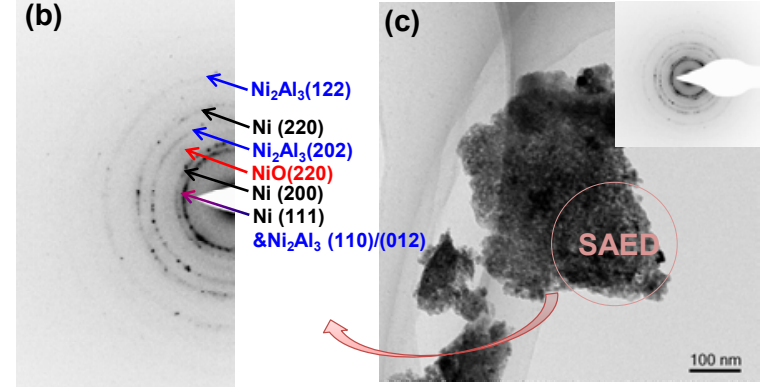

Fig. 5. XRD pattern (a), analysis of SAED (b), and low magnification TEM image (c) of the passivated RQ Ni-Al-FC catalyst. The XRD analysis referred to JCPDS cards (65-3454, 65-0380, 65-2901).

destroyed in the combusted RQ Ni-Al-FC sample.

The structural features of the passivated RQ Ni-Al-FC sample were totally different from those of the combusted RQ Ni-Al-FC sample. The SAED pattern (Fig. 5) showed the intensity of the $\mathrm{NiO}$ diffraction ring was very weak and no $\mathrm{NiO}$ peak was detected by XRD pattern, which indicated that there was only a small amount of the NiO phase in the passivated RQ Ni-Al-FC sample. The HRTEM images displayed that the structure of the RQ Ni-Al-FC catalyst was almost same with that

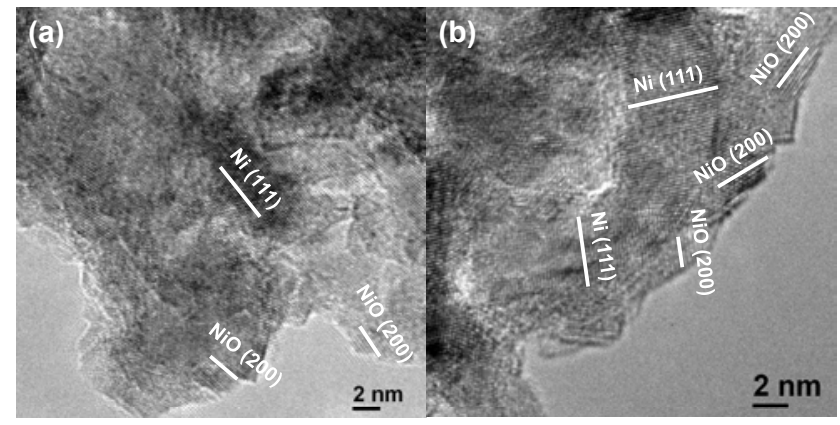

Fig. 6. HRTEM images of passivated RQ Ni-Al-FC catalyst.

of the pristine one excepted for the formation of a thin layer of $\mathrm{NiO}$ on the surface, as shown in Fig. 6. Thus, the passivation method can also provide valuable information about the RQ $\mathrm{Ni}$-Al-FC catalyst.

The surface morphology of the passivated RQ Ni-Al-FC sample in the SEM images showed a large number of pores uniformly distributed in the whole sample, which may allow more active sites to be exposed for the catalytic reaction. The TEM image further displayed that the particle size was small, uniform, and the same with that of the pristine sample. The STEM-EDS elemental mappings (Fig. 7) showed that the constituent elements, $\mathrm{O}, \mathrm{Al}, \mathrm{Cr}, \mathrm{Fe}$, and $\mathrm{Ni}$, were homogeneously distributed in small aggregates and the outer part of big aggregates, but the distribution of $\mathrm{Al}$ was not uniform in the inner part of big aggregates. The reason was that the alkaline extraction was not strong enough to remove more inner Al. The EELS spectrum of the passivated RQ Ni-Al-FC sample (Fig. 8) revealed almost the same results with that of the RQ Ni-Al-FC sample. The increasing of the oxygen peak intensity was due to the NiO layer on the surface.

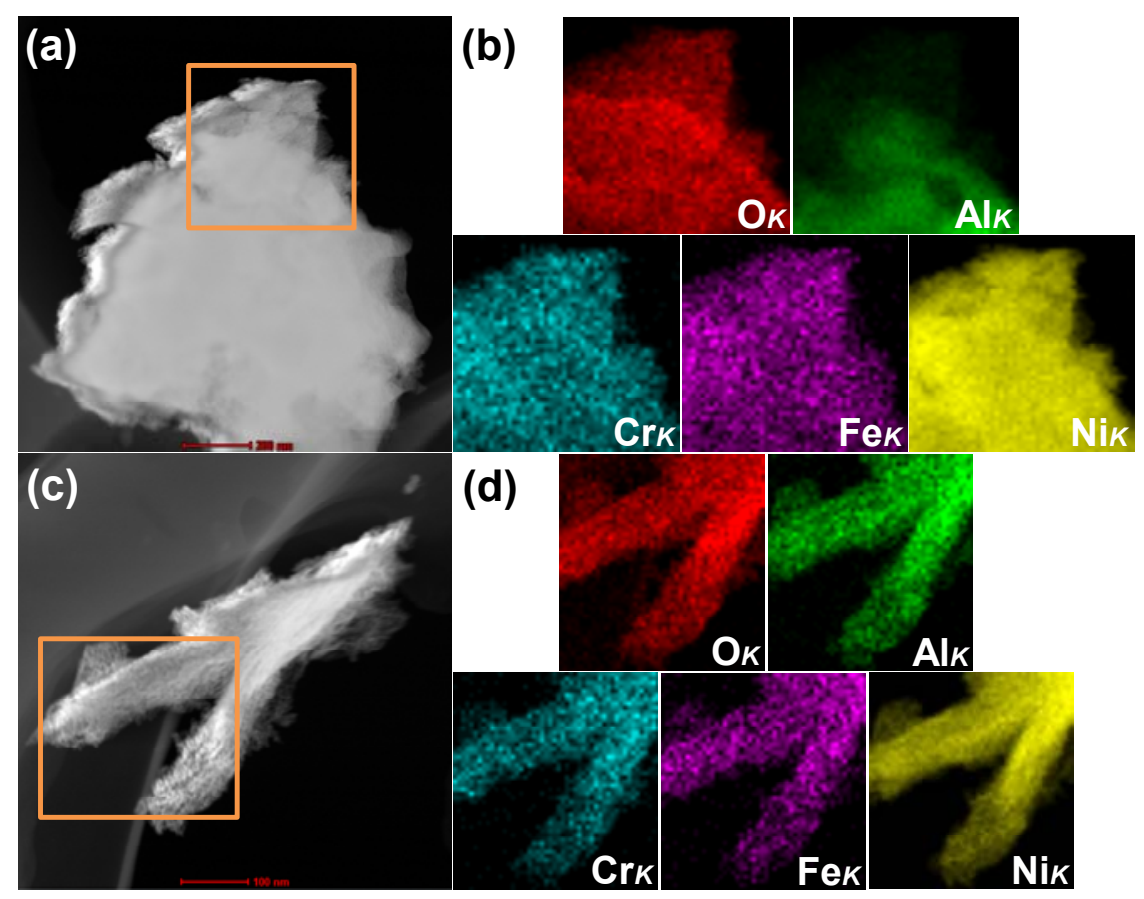

Fig. 7. STEM-EDS elemental mapping of passivated RQ Ni-Al-FC catalyst. 


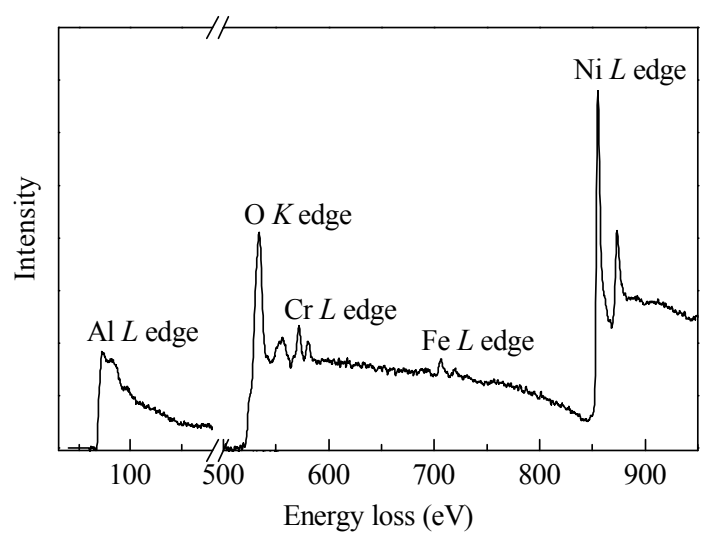

Fig. 8. EELS spectrum of passivated RQ Ni-Al-FC catalyst, showing $\mathrm{Al} L$ $\mathrm{O} K, \mathrm{Cr} L, \mathrm{Fe} L$, and Ni $L$ edges.

It is critical to illustrate the nature of the active phase of the RQ Ni-Al-FC catalyst. Based on the microscopic features discussed and its performance in catalytic reactions (e.g., adsorptive desulfurization of light oil distillates [24]), the Ni nanocrystal is the main phase exposed on the surface, which would be the catalytically active phase in the catalyst. The existence of a little bit of $\mathrm{NiO}$ would be due to oxidation in the ethanol during storing. The active Ni phase should be fixed and exposed on the catalyst surface, but it is not stable due to its magnetism. Therefore, the $\mathrm{Ni}_{2} \mathrm{Al}_{3}$ phase plays the role of a skeleton, and the Al must be extracted by alkaline extraction for exposing more active $\mathrm{Ni}$ when it is used as a catalyst. The doped $\mathrm{Fe}$ and $\mathrm{Cr}$ in the RQ Ni-Al-FC catalyst were highly dispersed, and may also be the active site in some reactions or can tune the fine structure of Ni to promote its performance, such as increasing the defects in the Ni phase.

\section{Conclusions}

The structural features of a RQ Ni-Al-FC catalyst were systematically investigated in terms of the crystal structure, electronic structure, and chemical composition. The passivation method can provide some crucial structural information on the phase composition, elemental distribution, and the sub-surface.
Microscopy investigation by a vacuum transfer holder combined with the passivation method can reveal the microstructure information of air-sensitive Raney-type catalyst to contribute to exploring and understanding their synthesis-structure-performance relationship. The structural features of fresh and used RQ Ni-Al-FC catalyst should be studied in the future because this will help reveal the active site variations in catalytic reactions.

\section{References}

[1] Zong B N. Catal Surv Asia, 2007, 11: 87

[2] Zong B N, Mu X H, Zhang X X, Meng X K, Qiao M H. Chin J Catal (宗 保宁, 慕旭宏, 张晓昕, 孟祥堮, 乔明华. 催化学报), 2013, 34: 828

[3] Meng X K, Mu X H, Zong B N, Min E Z, Zhu Z H, Fu S B, Luo Y B. Catal Today, 2003, 79-80: 21

[4] Liu B, Qiao M H, Deng J F, Fan K N, Zhang X X, Zong B N. J Catal, 2001, 204: 512

[5] Hu H R, Qiao M H, Pei Y, Fan K N, Li H X, Zong B N, Zhang X X. Appl Catal A, 2003, 252: 173

[6] Hu H R, Qiao M H, Wang S, Fan K N, Li H X, Zong B N, Zhang X X.J Catal, 2004, 221: 612

[7] Hu H R, Xie F Z, Pei Y, Qiao M H, Yan S R, He H Y, Fan K N, Li H X, Zong B N, Zhang X X.J Catal, 2006, 237: 143

[8] Sun B, Lin J, Xu K, Pei Y, Yan S R, Qiao M H, Zhang X X, Zong B N. ChemCatChem, 2013, 5: 3857

[9] Luo G, Yan S R, Qiao M H, Zhang K, Hu H R, He H Y, Fan K N. Chem Res Chin Univ, 2004, 20: 452

[10] Mu X H, Zong B N, Min E Z, Wang X, Wang Y, Zhang X X, Shu X T. US Patent 6368996. 2002

[11] Zhang X X, Zong B N, Min E Z. ACS Div Petrol Chem Prepr, 2002, 47: 387

[12] Xie F Z, Chu X W, Hu H R, Qiao M H, Yan S R, Zhu Y L, He H Y, Fan K N, Li H X, Zong B N, Zhang X X. J Catal, 2006, 241: 211

[13] Wang W Y, Yang Y Q, Luo H A, Liu W Y. Catal Commun, 2010, 11: 803

[14] Devred F, Hoffer B W, Sloof W G, Kooyman P J, van Langeveld A D, Zandbergen H W. Appl Catal A, 2003, 244: 291

[15] Lei H, Song Z, Tan D L, Bao X H, Mu X H, Zong B N, Min E Z. Appl Catal A, 2001, 214: 69

[16] Hu H R, Qiao M H, Xie F Z, Fan K N, Lei H, Tan D L, Bao X H, Lin H L, Zong B N, Zhang X X.J Phys Chem B, 2005, 109: 5186

[17] Potapov P L, Kulkova S E, Schryvers D, Verbeeck J. Phys Rev B,

\section{Graphical Abstract}

Chin. J. Catal., 2015, 36: 1662-1667 doi: 10.1016/S1872-2067(15)60925-1

\section{Microstructure of rapidly quenched $\mathrm{Ni}-\mathrm{Al}$ based catalysts by advanced electron microscopy}

Bingsen Zhang, Aiguo Zheng, Xiaoli Pan, Yiming Niu, Xiaoxin Zhang, Dangsheng Su*, Baoning Zong*

Institute of Metal Research, Chinese Academy of Sciences;

Research Institute of Petroleum Processing, Sinopec

The microstructural features of rapidly quenched Ni-Al alloy doped with $\mathrm{Fe}$ and $\mathrm{Cr}$ were investigated by advanced electron microscopy, which gave valuable information for exploring their synthesisstructure-performance relationship.

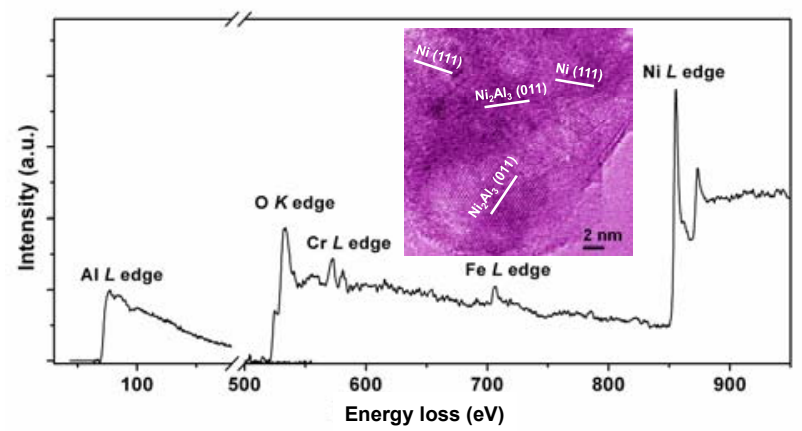


2001, 64: 184110

[18] Potapov P L, Kulkova S E, Schryvers D. J Microsc, 2003, 210: 102

[19] Feldhoff A, Martynczuk J, Arnold M, Myndyk M, Bergmann I, Sepelak V, Gruner W, Vogt U, Hahnel A, Woltersdorf J. J Solid State Chem, 2009, 182: 2961

[20] McBride S P, Brydson R.J Mater Sci, 2004, 39: 6723
[21] Wang C M, Baer D R, Amonette J E, Engelhard M H, Antony J, Qiang Y.J Am Chem Soc, 2009, 131: 8824

[22] Colliex C, Manoubi T, Ortiz C. Phys Rev B, 1991, 44: 11402

[23] Wang H J, Gu X J, Poon S J, Shiflet G J. Phys Rev B, 2008, 77: 014204

[24] Zong B N, Meng X K, Lin H L, Zhang X X, Mu X H, Min E Z. US Patent 6875340.2005

\title{
急冷镍铝基催化剂微结构的电子显微学研究
}

\author{
张炳森 $^{\mathrm{a}, \dagger}$ ，郑爱国 ${ }^{\mathrm{b}, \dagger}$ ，潘晓丽 ${ }^{\mathrm{a}}$ ，牛一鸣 ${ }^{\mathrm{a}}$, 张晓昕 ${ }^{\mathrm{b}}$, 苏党生 ${ }^{\mathrm{a},{ }^{*}}$, 宗保宁 ${ }^{\mathrm{b}, \#}$ \\ ${ }^{\mathrm{a}}$ 中国科学院金属研究所沈阳材料科学国家(联合) 实验室, 辽宁沈阳 110016 \\ ${ }^{\mathrm{b}}$ 中国石油化工股份有限公司石油化工科学研究院石油化工催化材料与反应工程国家重点实验室, 北京100083
}

\begin{abstract}
摘要: 雷尼镍型催化剂以其优越的电、磁、机械及化学等性能而广泛应用于石油化工领域. 该类催化剂通常使用急冷法制备, 以 获得亚稳态均匀的非晶或纳米晶合金结构. 例如急冷镍铝合金在一些不饱和有机化合物加氢反应中展现了卓越性能. 通过引入 杂原子, 可调控其活性、抗酸性和磁性等, 如铁掺杂可以增加磁性, 满足磁分离技术和磁稳定床的需求; 耐腐蚀铬的加入能够使催 化剂适应酸性反应体系. 热稳定性和比表面积调控对提高雷尼镍型催化剂的性能起重要作用, 而这些取决于材料的相组成、晶粒 尺寸、孔径分布和杂原子引入等微观结构. 因此, 精细结构解析对急冷镍铝基催化剂活性、选择性和转化率的研究起重要作用. Devred等通过真空传递样品台在透射和高分辨模式中研究了雷尼镍型催化剂的结构, 并与其性能关联. 除此, 关于此类材料精细 结构解析的文献很少. 主要原因是此类催化剂在空气中易燃烧, 不易得到其真实的微结构特征. 此外, 磁性对利用透射电子显微 镜原子级别探索其微观结构也有很大影响. 基于X射线衍射(XRD)和X射线光电子能谱(XPS)对雷尼镍型催化剂的研究, 利用先进 电子显微学探索其精细结构是非常重要的研究方向. 本文借助真空传递样品台, 使用电子显微术和电子能量损失谱探索铁铬掺 杂急冷镍铝合金催化剂的微结构, 揭示了催化剂真实结构, 并详细对比分析了原始、燃烧及针化处理催化剂的结构特征. 该工作 将为研究急冷镍铝基催化剂 “合成-结构-性能”关系提供真实的结构特征信息.

利用真空传递样品台, 我们通过选区电子衍射(SAED)和XRD确定了铁铬掺杂镍铝合金是由 $\mathrm{Ni}_{2} \mathrm{Al}_{3}$ 和 $\mathrm{Ni}$ 组成. 扫描透射模式 中, $\mathrm{X}$ 射线能谱(EDS)元素面扫显示 $\mathrm{Fe}, \mathrm{Ni}, \mathrm{Cr}, \mathrm{Al}$ 和 $\mathrm{O}$ 元素均匀分布于催化剂中, 并确定了其成分比例. 样品中氧的存在是由于存 放样品时少量镍被氧化, 高分辨解析也进一步证实了样品中有少量氧化镍. 高分辨分析也给出催化剂中 $\mathrm{Ni}$ 和 $\mathrm{Ni}_{2} \mathrm{Al}_{3}$ 的分布, 大部 分 $\mathrm{Ni}$ 分布在表面, $\mathrm{Ni}_{2} \mathrm{Al}_{3}$ 在样品中起骨架作用. 电子能量损失谱揭示 $\mathrm{Ni}$ 和 $\mathrm{Fe}$ 的存在形式为金属态, 而 $\mathrm{Cr}$ 为氧化物. 进一步对比分 析了原始、燃烧和针化的铁铬掺杂镍铝催化剂的微结构. 结果表明, 燃烧后的催化剂结构发生巨大变化, 含有大量氧化镍, 原始结 构完全被破坏. 但经过钝化处理样品的体相微结构未发生变化, 颗粒尺寸、组成元素分布和体相相组成与原始催化剂相同, 表面 有一层氧化镍生成. 钝化使得表面生成氧化镍层, 可保护样品不被进一步氧化. 对其微结构解析中发现大颗粒中铝含量高, 说明 碱提取铝过程中不完全, 如果调控合成颗粒尺寸分布均一的催化剂, 将会增加催化剂中的活性组分, 提高其性能.

综上所述, 对比分析原始、燃烧和钝化样品的精细结构表明, 利用真空传递样品台可以揭示铁铬掺杂急冷镍铝催化剂的真实 结构; 针化处理样品的体相结构分析可以代表原始催化剂元素分布、体相相组成及颗粒尺寸分布等特征. 这些微结构特征解析将 有助于进一步研究催化反应机制和理解反应路径等. 本文为分析易氧化和具有磁性的催化剂提供了微结构解析方法, 如果能够 用此方法对比分析反应前后催化剂的微结构, 将对设计合成高性能催化剂提供重要依据.
\end{abstract}

关键词: 镍铝基催化剂; 电子显微学; 光谱学; 真空传递样品杆; 微结构

收稿日期: 2015-04-03. 接受日期: 2015-06-03. 出版日期: 2015-10-20.

*通讯联系人. 电话: (024)23971577; 传真: (024)83970019; 电子信箱: dssu@imr.ac.cn

\#通讯联系人. 电子信箱: zongbn.ripp@sinopec.com

†同等贡献作者.

基金来源: 石油化工催化材料与反应工程国家重点实验室(中国石油化工股份有限公司石油化工科学研究院)开放基金; 中国科 学院金属研究所创新基金; 中国科学院青年创新促进会基金.

本文的英文电子版由Elsevier出版社在ScienceDirect上出版(http://www.sciencedirect.com/science/journal/18722067). 